\title{
肺癌骨転移の検討
}

\section{Bone Metastases of Primary Lung Cancer}

川崎雅之・原 信之・一瀬幸人・本広 昭・久田友治

麻生博史・近間英樹・清水哲哉 · 大田満夫 ·奏 一雄*

\begin{abstract}
要旨：原発性肺癌患者1180例のうち診断時に骨転移を認めた185例 (15.7\%)に対して検討を加 えた。組織型では腺癌, 小細胞癌に比べ扁平上皮癌に骨転移が少なく，また腺癌では多 発性骨転移が多い傾向にあった．診断面では骨シンチが $98.2 \%$ 陽性を示したのに対し， 骨X線では69.2\%の陽性しか認められなかった.骨転移症例の中間生存期間は 5.5 月で 予後は不良であった，放射線治療の有効性は $67.7 \%$ あった.
\end{abstract}

〔肺癌 30 (3) : 359 364，1990〕

Key words : Bone metastasis, Lung cancer, Bone scintigraphy.

\section{I 、はじめに}

原発性肺癌における骨転移の頻度は13～44\% で1) 4), 乳癌, 前立腺癌などに次いで高いとされ ている.また最近の肺癌の増加に伴い, 臨床の 場で肺癌の骨転移に遭遇する機会も多い。骨転 移は骨シンチ，骨X線，症状，経過などより総 合的に診断されているのが一般的であるが，骨 シンチ，骨X線などで苦慮する場合も少なくな い. 症状としては疼痛が最も問題であり, いか にコントロールし, 患者のPerformance Status を改善させるかが臨床医にとって大きな問題で ある。

我々は肺癌骨転移症例185例に対して，骨転移 の臨床的特徵ならびに治療成績について検討を 加えたので報告する.

\section{II . 対象および方法}

1979年から1988年までの10年間に国立病院九 州がんセンタ一呼吸器部に入院し, 細胞診ある いは組織診で原発性肺癌と診断された1180例を

国立病院九州がんセンター呼吸器部 放射線部
対象とした，骨転移の診断は，全例に ${ }^{99 \mathrm{~m}} \mathrm{Tc}$-リ ン酸化合物による骨シンチを行ない，取り込み のある部位(骨シンチ陽性とする) あるいは疼痛 のある部位に対し骨X線を撮影した。骨X線で, 溶骨性あるいは造骨性変化が認められれば骨転 移有りとした。骨シンチのみ陽性例では, その 後の骨シンチ, 骨X線, 臨床症状などの変化を 追跡した. 以上の骨シンチ, 骨 X線, 臨床所見, 経過より総合的に骨転移の有無を判定した。な お診断時，または治療開始前に骨転移がありと された症例を骨転移例とし，それ以後の経過中 に出現した骨転移は除外した。また骨への直接 浸潤例は除外した。生存期間は診断確定日より の期間を用い，統計学的分析は $\chi^{2}$ 検定にて $\mathrm{p}<$ 0.05を有意とした。

\section{III. 成 績}

\section{1）組織型別骨転移発生頻度}

組織型別 IV 期症例ならびに骨転移症例の頻度 を示した.1180例中 IV 期症例は344例 (29.2\%) あ ク，そのうちで骨転移は185例 (15.7\%)に認めら れた。 185例中105例 $(56.8 \%)$ は転移が骨のみに 
Table 1. Number of patients with primary lung cancer between 1979 and 1988.

\begin{tabular}{lcccccc}
\hline & Squamous & Adenoca. & Small & Large & Others & Total \\
\hline Lung cancer & 345 & 563 & 128 & 97 & 47 & 1180 \\
& $(29.2 \%)$ & $(47.7 \%)$ & $(10.8 \%)$ & $(8.2 \%)$ & $(4.1 \%)$ & \\
Stage IV & 55 & 194 & 45 & 40 & 10 & 344 \\
Bone metastasis & $(16.0 \%)$ & $(56.4 \%)$ & $(13.1 \%)$ & $(11.6 \%)$ & $(2.9 \%)$ & \\
& 26 & 112 & 25 & 13 & 9 & 185 \\
\hline
\end{tabular}

Squamous: squamous cell carcinoma, Adenoca.: adenocarcinoma, Small: small cell carcinoma, Large: large cell carcinoma.

Table 2. Frequency of bone metastasis according to histologic type.

\begin{tabular}{|c|c|c|}
\hline \multicolumn{3}{|l|}{ Squamous cell carcinoma $7.1 \%(26 / 345)$} \\
\hline Adenocarcinoma $\quad 19.9 \%(112 / 563)$ & $\mathrm{p}<0.0005$ & $\mathrm{p}<0.0005$ \\
\hline Small cell carcinoma $19.5 \%(25 / 128)$ & & \\
\hline Large cell carcinoma $13.4 \%(13 / 97)$ & & \\
\hline
\end{tabular}

Table 3. Distribution of bone metastasis.

\begin{tabular}{lc}
\hline Location & No. of patients(\%) \\
\hline Skull & $25(13.5 \%)$ \\
Cervical spine & $19(10.3 \%)$ \\
Thoracic spine & $84(45.4 \%)$ \\
Lumbar spine & $76(41.1 \%)$ \\
Sacrum & $2(1.1 \%)$ \\
Clavicle & $7(3.8 \%)$ \\
Sternum & $7(3.8 \%)$ \\
Rib & $91(49.2 \%)$ \\
Scapula & $17(9.2 \%)$ \\
Humerus & $11(5.9 \%)$ \\
Pelvis & $72(38.9 \%)$ \\
Femur & $28(15.1 \%)$ \\
Tibia & $7(3.8 \%)$ \\
Tarsal bone & $1(0.5 \%)$ \\
\hline
\end{tabular}

限局していた。骨転移症例の組織型は腺癌が最 も多く $60.5 \%$ を占め, 次いで扁平上皮癌 $14.1 \%$, 小細胞癌 $13.5 \%$, 大細胞癌 $7.0 \%$ の順であった (Table 1).

各組織型における骨転移の頻度は, Table 2 に 示すごとく腺癌 $19.9 \%$, 小細胞癌 $19.5 \%$, 大細 胞癌 $13.4 \%$ の順で, 扁平上皮癌は $7.1 \%$ と最も低 かった。扁平上皮癌症例における骨転移発生頻 度は腺癌, 小細胞癌に比べて有意に低かった $(\mathrm{p}<0.0005)$.

\section{2 ) 骨転移の部位}

Table 4. Frequency of solitary and multiple bone metastases according to histologic type.

\begin{tabular}{crccc}
\hline & Squamous & Adenoca. & Small & Large \\
\hline Solitaly & $8(30.8 \%)$ & $25(22.3 \%)$ & $8(32.0 \%)$ & $4(30.8 \%)$ \\
Multiple & $18(69.2 \%)$ & $87(77.7 \%)$ & $17(68.0 \%)$ & $9(69.2 \%)$ \\
\hline
\end{tabular}

Squamous: squamous cell carcinoma, Adenoca.: adenocarcinoma, Small: small cell carcinoma, Large: large cell carcinoma

Table 5. Bone scintigraphy, bone $X-p$, and pain of patients with bone metastases.

\begin{tabular}{c|ccc}
\hline Bone scintigraphy & Bone X-p & Pain & No. of patients \\
\hline \multirow{4}{*}{+} & + & + & $92(53.8 \%)$ \\
& & - & $24(14.0 \%)$ \\
\cline { 2 - 4 } & - & + & $22(12.9 \%)$ \\
\hline- & + & - & $30(17.5 \%)$ \\
\hline
\end{tabular}

骨転移発生部位は胁骨が最も多く $49.2 \%$ を示 L, 以下胸椎 $45.4 \%$, 腰椎 $41.1 \%$, 骨盤骨 38.9 \%の順であった，四肢骨の転移は比較的少なく， 特に上下肢遠位部への転移は下腿骨, 足背に 4.3 \%を認めたにすぎなかった(Table 3).

\section{3 ) 骨転移の数}

185例中45例 (24.3\%) が単発性，140例 (75.7 \%)が多発性骨転移であった。組織型別に単発, 多発の頻度をみると, 腺癌に扔ける単発性骨転 移の頻度が他の組織型に比べ低かったが, 各組 織間に統計学的有意差は認めなかった (Table 4).

4 ）骨シンチ, 骨X 線, 疼痛の陽性頻度ならび に経過

診断は自覚症状 (疼痛, 麻痺など), 検查 (骨シ 
Fig. 1. Survival curves of stage IV patients with or without bone metastasis.

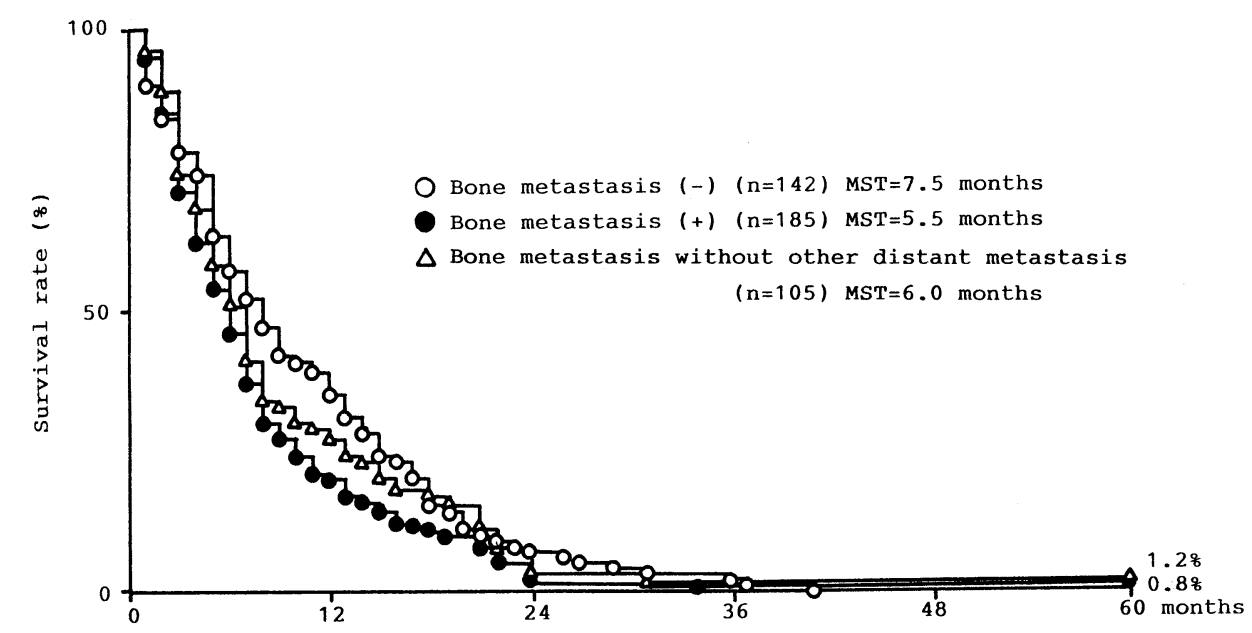

ンチ, 骨X線), ならびに経過より総合的に行な

った. Table 5に示すように, 骨シンチの感度が 最も高く $98.2 \%$ が陽性を示し，骨X線は69.6\%， 疼痛は $68.4 \%$ であった。骨シンチ, 骨X 線, 疼 痛すべてに陽性を示していたものは $53.8 \%$ にす ぎなかった。また，症状もなく，骨X線も無所 見で骨シンチのみが陽性である症例も $17.5 \%$ 存 在した。

骨シンチのみ陽性であった 30 例に対し経過を 追跡した。その後の経過で骨X線または疼痛が 陽性に変化したのは18例であり，それまでの期 間は 1 カ月から 22 月までとかなりのばらつき が認められ, 骨X線では平均 9 力月後, 疼痛で は平均 7 力月後に陽性に変化した。 疼痛出現も なく, 骨X線にも変化が認められなかった 12 例 は，早期死亡例あるいは早期退院例が多く平均 5 力月の経過観察しかできていなかった。また その中の 1 例は21力月もの間, 骨X線変化, 疼 痛が出現せず，剖検にて骨転移が確認された。

5 ) 予 後

Kaplan-Meier法を用い，IV 期症例中骨転移 ありの群(185例), 骨転移なしの群(142例), 転 移が骨のみの群(105例)に対して生存曲線を求 めた。骨転移のない IV 期群ではMST (Median Survival Time) は7.5力月であったが，骨転移 ありの群ではMSTが5.5力月と有意に短かった $(\mathrm{p}<0.02)$ 。また転移が骨のみの群でもMSTが
6 カ月と骨転移なしの群に比べると短かったが 有意差は認められなかった。

6 ) 治 療

103例 (55.6\%)に扔いて疼痛コントロール, 骨 折予防のため，局所に放射線照射 $30 \sim 51.2 \mathrm{~Gy}$ (平均40Gy) が行なわれていた. 治療効果を疼痛 の面から検討すると評価可能例 96 例中65例 $(67.7 \%)$ に症状の軽減ないし消失を認めた。ま た化学療法のみで軽減している症例も 3 例認め られた。放射線治療無効例31例においては, 組 織型, 単発, 多発, 他臓器への転移の有無など の割合は全体とほぼ同じであったが，骨X線変 化例が31例中 26 例 $(84 \%)$ と多く，またMSTも 4.5力月と短かった。

\section{IV. 考 察}

原発性肺癌の骨転移に関しては，さまざまな 報告がなされている. 剖検例では, Johnston ${ }^{11}$ は 122例中 54 例 (44\%), Napoli ら ${ }^{21}$ は 110例中38例 (35\%) と報告している。骨 X 線診断では,

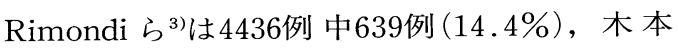
ら ${ }^{4)}$ は335例中 44 例 (13\%) に骨転移を認めてい る。骨シンチに関しては30４0\%の報告が認め られる ${ }^{5), 6)}$. 中野ら ${ }^{6}($ は骨シンチで治療前の 69 例 中12例 $(17.4 \%)$ に骨転移を認めたとしている. 我々の結果では, 1180例中185例 (15.7\%) と比較 的低い頻度になっている。これは診断時に限っ 
た骨転移発生率であること，また以前に比べて 早期に肺癌の診断がつくようになったことが理 由として考えられる。

組織型による骨転移発生率に関しては, 報告 により腺癌が最も高いとするもの7)や, 大細胞 癌8), 小細胞癌9)が最も高いとするものなどいろ いろだが, 扁平上皮癌で骨転移発生率が低いの は一致している. 我乃の結果でも腺癌, 小細胞 癌に比べて，扁平上皮癌は統計学的に有意に低 い傾向を認めた。

骨転移の発生部位に関しては, 従来の報告5),8 にみられるように胁骨, 脊椎骨, 腸骨に多かっ た。これは脊椎静脈叢の関与, 赤色髄の存在が 原因と考之られている ${ }^{10)}$. また骨転移が少ない とされている四肢遠位骨は, 我々の結果でも 4.3 \%に認めたにすぎなかった。単発性骨転移は扁 平上皮癌に多く, 腺癌には少ないと松井ら ${ }^{5)}$ 報告しているが, 我々の結果でも有意差はない が, 腺癌は他の組織型に比べ, 単発性骨転移が 少ない傾向，すなわち多発性骨転移が多い傾向 にあった。

診断に関しては, 確定診断である骨生検が疼 痛，骨折などの合併症があり容易に施行できず, 画像診断 (骨X線, 骨シンチ), 疼痛などの症状 などにより総合的に診断が行なわれていた。骨 X線が69.6\%しか陽性を示していなかったのに 対し, 骨シンチは $98.2 \%$ 感度が高かった。ま た骨シンチの陰性例も 3 例 (1.8\%)に認めた。

Franklin ${ }^{11)}$ は転移性骨腫瘍中, 骨シンチ陽性・骨 X線陰性は約 $1 / 3$ の症例に, また骨シンチ陰性・ 骨 X線陽性は $2 \sim 8 \%$ に認めるとしている. 我々の結果でもそれぞれ $30.4 \%, 1.8 \%$ を示し， ほぼ同じ頻度であった，従来，骨X線は骨シン チに比べ 3 ～6 カ変化が遅れるとされてお $\eta^{12), 13)}$, 理由として転移巣の直径が $1 \sim 1.5 \mathrm{~cm}$, 骨が50〜75\%まで破壊されないと単純骨X線で は変化が現れないとされている11).我々は骨シ ンチのみ陽性の16例に対し経過を追うことがで きたが，骨X線変化までは 1 力月から 22 月ま
での範囲があり，かなりのばらつきを認め，一 概に $3 \sim 6$ 力月 X線変化が遅れるとは, 少なく とも肺癌の骨転移に関しては言えないのではな いかと考えられた。

予後に関してはGravensteinら ${ }^{14)}$ は骨シンチ 陽性者 46 例中 40 例が 6 力月以内に死亡したと報 告しており，他にも骨転移を予後不良因子の 1 つとする報告が認められる。我々の結果でも MSTが5.5力月で骨転移のない IV 期群の7.5力 月と比べて有意に短い傾向を認めた。また多臓 器転移が予後不良因子になっている可能性を除 く目的で骨にのみ転移がある群についても調べ たが, MSTは 6 カ月であり骨転移のない $\mathrm{I}$ 期群 と比べると短かったが有意差は認めなかった。 治療に関しては疼痛コントロールあるいは骨 折予防のために局所に放射線治療が行なわれて おり，96例中65例 $(67.7 \%)$ に疼痛軽減ないしは 消失を認女た. Daphneら ${ }^{15)}$ は1016例の転移性骨 腫瘍の疼痛に対する放射線治療の効果について 検討しているが, 疼痛の軽減が $90 \%$, 疼痛の消 失が54\%に認められたと報告している。また放 射線治療無効例には, 骨 X線変化例が $84 \%$ と比 較的多かったことより, 早期の放射線治療開始 が望ましいと考えられた。

\section{V.まとめ}

1 ) 原発性肺癌患者1180例のうち, 䛦断時185例 (15.7\%)に骨転移を認めた。そのうち転移が骨 のみであるのは105例 (56.8\%)であった。

2 ) 組織型別では腺癌, 小細胞癌に比べ扁平上 皮癌に有意に骨転移が少ない傾向にあった。

3 ) 腺癌では多発性骨転移が多い傾向にあった.

4 ）骨シンチ $98.2 \%$, 骨X線 $69.6 \%$, 疼痛 68.4 \%の陽性率を示し, 骨シンチの感度が高かった。 5 ）骨転移症例は中間生存期間が5.5力月であ $\eta$ ，他の $\mathrm{I}$ 期症例に比べ有意に予後が悪かった. また骨にのみ転移があった症例の中間生存期間 は 6 カ月であった。

6 ）放射線治療の有効性は $67.7 \%$ あっった。 
文 献

1) Johnston, A.D. : Pathology of metastatic tumors in bone. Clinical Orthopaedics and Related Research, 73: 8-32, 1970.

2) Napoli, L.D., Hansen, H.H., Muggia, F.M., et al. : The incidence of osseous involvement in lung cancer, with special reference to the development of osteoblastic changes. Radiology, 108: 17-21, 1973.

3) Rimondi, C., Bernardi, L., Cammoranesi, L. : Le metastasi scheletriche ematogene de cancro broncogeno, G. Clin. Med., $50: 578-600$, 1969 .

4）木本龍也, 中田肇, 大野正人：肺癌の骨転 移-X線所見について一. 肺癌, 18：31-37, 1978.

5）松井律夫, 西山章次, 楢林 勇, 他: 原発性肺 癌の骨シンチグラフィーの検討. 肺癌, 25 (1) : 71-76, 1985.

6）中野俊一, 長谷川義尚, 梶田明義, 他：骨シン チグラフィーによる肺癌骨転移の検討。核医 学, $20: 37-43,1983$.

7) Strauss, B. : Bronchogenic carcinoma A statistical analysis of two hundred ninety-six cases with necropsy as to relationships between cell type and age, sex, and metastases. Arch. Pathol., 63 : 602-611, 1957.

8）阿部光延, 大出良平, 尾形利郎：肺癌の ${ }^{99 \mathrm{~m}} \mathrm{Tc}^{-}$ MDPによる骨シンチグラフィー。臨床放射線,
$27: 621-625,1982$.

9) Hansen, H.H. : Staging of inoperable patients with bronchogenic carcinoma with special reference to bone marrow examination and peritoneoscopy. Cancer, $30: 1395$ 1401, 1972.

10）天野 厳: 肺癌の骨，骨䯣転移一特に脊椎静 脈，赤色髄分布との関連一。臨床放射線，17： 937-948, 1972.

11) Franklin, H.S., ed. : Diagnosis and Management of Metastatic Bone Disease; A multidisciplinary approach. Raven Press, New York, 1988.

12) Greenberg, E.J., Weber, D.A., Pochaczevesky, R. et al. : Detection of neoplastic bone lesions by quantitative scanning and radiography. J. Nucl., 9 : 613-620, 1968.

13) Donato, A.T., Ammerman, E.G., Sullesta, O. : Bone scanning in the evaluation of patients with lung cancer. Ann. Thorac. Surg. $27: 300-304,1979$.

14) Gravenstein, S., Peltz, M.A., Pories, W. : How ominous is an abnormal scan in bronchogenic carcinoma? J. Am. Med. Assoc., 241 : 2523-2524, 1979.

15) Daphne, T., Laurence, G., Frank, R.H. : The palliation of symptomatic osseous metastases. Cancer 50:893-899, 1982. 


\title{
Bone Metastases of Primary Lung Cancer
}

\author{
Masayuki Kawasaki, Nobuyuki Hara, Yukito Ichinose, Akira Motohiro, \\ Tomoharu Kuda, Hiroshi Aso, Hideki Chikama, Tetsuya Shimizu, \\ Mitsuo Ohta and Kazuo Hata* \\ Department of Chest and Radiology*, \\ National Kyushu Cancer Center.
}

Bone metastases were reviewed among 1,180 patients with lung cancer who were treated at the National Kyushu Cancer Center. The metastases were detected in 185 patients $(15.7 \%)$ on initial staging. According to the histologic type, the metastatic rate in patients with squamous cell carcinoma was low (7.1\%) as compared to that in patients with adenocarcinoma (19.9\%) and small cell carcinoma (19.5\%). Multiple bone metastases were seen more frequently in patients with adenocarcinoma than patients with other cell types. Median survival periods of patients who had bone metastases and other stage IV patients were 5.5 and 7.5 months, respectively. This difference on median survival time was statistically significant $(p<0.02)$, implying that bone metastases is a poor prognostic factor. Radiotherapy was used in order to reduce pain, and $67.7 \%$ achieved partial or complete pain relief. 